\section{Nitrogen Form Affects Growth, Mineral Nutrient Content, and Root Anatomy of Cotoneaster and Rudbeckia}

\author{
Helen T. Kraus and Stuart L. Warren \\ Department of Horticultural Science, North Carolina State University, Raleigh, \\ NC 27695-7609 \\ Charles E. Anderson \\ Department of Botany, North Carolina State University, Raleigh, NC27695-7612
}

Additional index words. root growth, Cotoneaster dammeri 'Skogholm', Rudbeckia fulgida

'Goldsturm', ammonium, nitrate, container-grown

Abstract. Five ratios of $\mathrm{NH}_{4}^{+}: \mathrm{NO}_{3}^{-}(100: 0,75: 25,50: 50,25: 75$, and 0:100) were evaluated for impact on growth of Cotoneaster dammeri Schneid. 'Skogholm' (cotoneaster), a woody ornamental shrub, and Rudbeckia fulgida Ait. 'Goldsturm' (rudbeckia), an herbaceous perennial. Nitrate alone decreased dry weight and leaf area of cotoneaster and rudbeckia compared with mixtures of $\mathrm{NH}_{4}{ }^{+}$and $\mathrm{NO}_{3}^{-}$and $\mathrm{NH}_{4}{ }^{+}$alone. Additionally, $\mathrm{NO}_{3}{ }^{-}$alone suppressed accumulation of cationic nutrients and $\mathrm{N}$ in cotoneaster, while mixes of $\mathrm{NH}_{4}^{+}$ and $\mathrm{NO}_{3}{ }^{-}$enhanced accumulation of nutrients in roots and shoots of rudbeckia compared with solutions containing either $\mathrm{NH}_{4}{ }^{+}$or $\mathrm{NO}_{3}{ }^{-}$alone. The steles of roots of cotoneaster and rudbeckia contained more secondary xylem with larger tracheary elements with a mix of $25 \mathrm{NH}_{4}^{+}: 75 \mathrm{NO}_{3}{ }^{-}$than with $\mathrm{NO}_{3}{ }^{-}$alone.

Developing a fertility program involves selecting fertilizer rates, and sources and ratios of nutrients, especially the form of $\mathrm{N}$ $\left(\mathrm{NH}_{4}{ }^{+}\right.$or $\left.\mathrm{NO}_{3}{ }^{-}\right)$. Nitrogen form affects mineral nutrient concentration of shoots and roots (Edwards and Horton, 1982; Rosen et al., 1990), growth rate and N uptake (Edwards and Horton, 1982), and root anatomy (Finn et al., 1990) of ornamental plants. Generally, increasing $\mathrm{NO}_{3}{ }^{-}$in fertilizer solutions stimulates organic anion synthesis and cation accumulation by the plant (Mengel and Kirkby, 1982). Active uptake of $\mathrm{NO}_{3}{ }^{-}$is believed to induce symport of cations; however, $\mathrm{NO}_{3}^{-}$uptake may also occur in exchange for $\mathrm{OH}^{-}$without cation symport (Mengel and Kirkby, 1982). In contrast, $\mathrm{NH}_{4}{ }^{+}$often suppresses the absorption of cations and synthesis of organic anions produced by plants, whereas inorganic anion accumulation $\left(\mathrm{SO}_{4}{ }^{2}, \mathrm{PO}_{4}{ }^{=}\right.$, and $\left.\mathrm{Cl}^{-}\right)$is increased (Mengel and Kirkby, 1982).

Growth of Douglas-fir [Pseudotsuga menziesii (Mirb.) Franco], especially root growth, was reduced by $\mathrm{NH}_{4}^{+}$as the only $\mathrm{N}$ source, while growth of lodgepole pine (Pinus contorta Dougl.) and Engelmann spruce (Picea engelmanni Parry) was reduced with $\mathrm{NO}_{3}^{-}$as the only $\mathrm{N}$-source when grown in sand and

Received for publication 27 Nov. 2000. Accepted for publication 6 June 2001. Research was funded in part by the North Carolina Agricultural Research Service (NCARS), Raleigh, NC 27695-7643. Use of trade names in this publication does not imply endorsement by the NCARS of products named nor criticism of similar ones not mentioned. The technical assistance of William Reece and Diane Mays, Analytical Service Laboratory, Dept. of Soil Science, and the statistical guidance of William Swallow are greatly appreciated.

Table 1. Nutrient solutions for each $\mathrm{NH}_{4}{ }^{+}: \mathrm{NO}_{3}{ }^{-}$ratio. metric compared to roots of cranberry (Vaccinium macrocarpon Ait. 'Searles') fertilized with $\mathrm{NH}_{4}{ }^{+}$that had rectangular epidermal cells (Finn et al., 1990). These differences in epidermal cell development were probably a result of less cell elongation with $\mathrm{NO}_{3}{ }^{-}$. Alterations in the phytohormone balance of the plant and differences in the assimilation pathways of $\mathrm{NH}_{4}^{+}$and $\mathrm{NO}_{3}{ }^{-}$in the root may account for the effect of $\mathrm{N}$ form on root morphology (Marschner, 1986).

As $\mathrm{N}$ form affects growth and may alter root growth, thereby impacting establishment in landscape plantings, there is need for more research on the effects of $\mathrm{N}$ form on landscape plants. Additionally, results of $\mathrm{N}$ form impacts on cotoneaster growth were conflicting, and no reports of the effect of $\mathrm{N}$ form on rudbeckia growth were found, nor were any reports found describing the anatomy of cotoneaster and rudbeckia roots. Therefore, our objective was to evaluate the effects of $\mathrm{N}$ form and ratio on growth, mineral nutrient accumulation, and root anatomy of cotoneaster, a woody ornamental shrub, and rudbeckia, a popular herbaceous perennial.

\section{Materials and Methods}

An experiment was conducted for 12 weeks (14 Oct. 1994 to 4 Jan. 1995) in a glass greenhouse in Raleigh, N.C. The experiment used a randomized complete-block design with seven replications (seven plants per $\mathrm{NH}_{4}{ }^{+}: \mathrm{NO}_{3}{ }^{-}$ treatment) and two species, cotoneaster 'Skogholm' and rudbeckia 'Goldsturm'. Nitrogen treatments included five $\mathrm{NH}_{4}{ }^{+}: \mathrm{NO}_{3}{ }^{-}$ ratios $(100: 0,75: 25,50: 50,25: 75$, and 0:100) (Table 1).

Cultural conditions. To facilitate complete recovery of root systems at harvest, rooted cotoneaster cuttings and rudbeckia seedlings were grown in 3.8-L containers filled with a substrate of arcillite (Turface, Aimcor Inc., Deerfield, Ill.), consisting of calcined montmorillite and illite clays. Arcillite was chosen as the container substrate because of its high moisture-holding capacity, good aeration, even retention of irrigation without channeling, and ease of removal from plant roots (Hiller and Koller, 1979). Temperatures were maintained at $24 \pm 3{ }^{\circ} \mathrm{C}$ day $/ 13 \pm 3{ }^{\circ} \mathrm{C}$ night under natural irradiance. Plants were covered with black cloth at 5:00 PM and provided with a daily night interruption from 11:00 PM to 2:00 AM using incandescent bulbs (photosynthetic photon flux of $3.6 \mu \mathrm{mol} \cdot \mathrm{m}^{-2} \cdot \mathrm{s}^{-1}$ plus photomorphogenic radiation of $0.7 \mathrm{~W} \cdot \mathrm{m}^{-2}$ ) and uncovered at 8:00 AM.

\begin{tabular}{lllccccc}
\hline \hline $\mathrm{NH}_{4}^{+}: \mathrm{NO}_{3}^{-}$ & \multicolumn{7}{c}{ Nutrient source } \\
\cline { 2 - 8 } ratio & $\mathrm{NH}_{4} \mathrm{NO}_{3}$ & $\mathrm{NH}_{4} \mathrm{Cl}$ & $\mathrm{KNO}_{3}$ & $\mathrm{Ca}\left(\mathrm{NO}_{3}\right)_{2}$ & $\mathrm{KH}_{2} \mathrm{PO}_{4}$ & $\mathrm{~K}_{2}\left(\mathrm{SO}_{4}\right)$ & $\mathrm{CaSO}_{4}$ \\
\hline $100: 0$ & & 3.5 & & & 0.32 & 0.96 & 1.25 \\
$75: 25$ & 0.875 & 1.75 & & & 0.32 & 0.96 & 1.25 \\
$50: 50$ & 1.75 & & & 0.32 & 0.96 & 1.25 \\
$25: 75$ & 0.875 & & 0.96 & 0.442 & 0.32 & & 0.834 \\
$0: 100$ & & & 0.96 & 1.27 & 0.32 & & \\
\hline
\end{tabular}

${ }_{1} 1.03 \mathrm{~mm} \mathrm{MgSO}_{4}, 0.09 \mathrm{~mm} \mathrm{Fe} \mathrm{DTPA,} 0.05 \mathrm{~mm} \mathrm{H}_{3} \mathrm{BO}_{3}, 0.0003 \mathrm{~mm} \mathrm{CuSO}_{4}, 0.009 \mathrm{~mm} \mathrm{MnCl}, 0.001 \mathrm{~mm}$. $\left(\mathrm{NH}_{4}\right)_{6} \mathrm{Mo}_{7} \mathrm{O}_{24}$, and $0.0008 \mathrm{~mm} \mathrm{ZnSO}_{4}$ supplied to each $\mathrm{NH}_{4}: \mathrm{NO}_{3}$ treatment. 
Ammonium : nitrate ratio treatments were administered twice daily (9:00 $\mathrm{AM}$ and 1:00 $\mathrm{PM})$ at $50 \mathrm{mg} \cdot \mathrm{L}^{-1} \mathrm{~N}$ and $450 \mathrm{~mL}$ per application (900 mL daily) via individual spray stake emitters (Spot-Spitter, Green $160^{\circ}$, Roberts Irrigation Products, San Marcos, Calif.) that dispersed nutrient solution treatments evenly over each container. A modified Hoagland solution was applied with the $\mathrm{NH}_{4}{ }^{+}: \mathrm{NO}_{3}{ }^{-}$ treatments to provide other mineral nutrients necessary for plant growth (Table 1). Nutrient solutions in stock tanks were changed weekly, and $\mathrm{pH}$ of nutrient solutions was checked daily and adjusted as needed with $\mathrm{NaOH}$ or $\mathrm{HCl}$ to maintain a $\mathrm{pH}$ of 6.0. To monitor substrate $\mathrm{pH}$, substrate solution displaced during the 1:00 PM irrigation with nutrient solution was collected on 25 Oct., 11 Nov., 23 Nov., 12 Dec., and 2 Jan. Substrate solution $\mathrm{pH}$ was measured for cotoneaster only with an Accumet $\mathrm{pH}$ meter (Fisher Scientific Co., Fairlawn, N.J.).

Plant growth and nutrient content. At harvest, roots were washed free of substrate. Stems, leaves, and roots were then washed with $0.1 \mathrm{~N} \mathrm{HCl}$, and rinsed with distilled water to remove any mineral nutrient residues. After washing, root length and root area were determined using an image analyzer (AgVision Monochrome System, Decagon Devices, Pullman, Wash.). Complete root systems of cotoneaster were measured. Due to their large size, root systems of rudbeckia were subsampled, measurements recorded, and data were adjusted following procedures developed by Thetford et al. (1995).

Stems, leaves, and roots were dried at 62 ${ }^{\circ} \mathrm{C}$ for $5 \mathrm{~d}$, weighed, and ground in a Wiley mill to pass a 40 -mesh $(0.425-\mathrm{mm})$ screen. Each tissue sample [root or shoot (cotoneaster, leaves + stem; rudbeckia, leaves)] (1.25 g) was combusted at $490{ }^{\circ} \mathrm{C}$ for $6 \mathrm{~h}$. The resulting ash was dissolved in $10 \mathrm{~mL} 6 \mathrm{~N} \mathrm{HCl}$ and diluted to 50 $\mathrm{mL}$ with deionized distilled water. Phosphorus, $\mathrm{K}, \mathrm{Ca}, \mathrm{Mg}, \mathrm{Mn}$, and $\mathrm{Fe}$ tissue concentrations were determined by inductively coupled plasma emissions spectrophotometer (P-2000; Perkin Elmer, Norwalk, Conn.). Nitrogen concentration was determined using $10-\mathrm{mg}$

Table 2. Effect of sample date and $\mathrm{NH}_{4}{ }^{+}: \mathrm{NO}_{3}{ }^{-}$ratio on substrate $\mathrm{pH}$ of cotoneaster.

\begin{tabular}{lccc}
\hline $\begin{array}{l}\text { Sample } \\
\text { date }\end{array}$ & $\mathrm{pH}$ & $\begin{array}{c}\mathrm{NH}_{4}{ }^{+}: \mathrm{NO}_{3}{ }^{-} \\
\text {ratio }\end{array}$ & $\mathrm{pH}$ \\
\hline 25 Oct. & 6.34 & $100: 0$ & 6.77 \\
11 Nov. & 6.56 & $75: 25$ & 6.89 \\
23 Nov. & 6.73 & $50: 50$ & 7.00 \\
12 Dec. & 6.92 & $25: 75$ & 6.74 \\
2 Jan. & 6.78 & $0: 100$ & 6.34 \\
Regression $^{z}$ & & & \\
L & 0.006 & & 0.001 \\
Q & 0.005 & & 0.001 \\
Contrasts $^{y}$ & & & \\
100:0 vs. mixes & --- & & $\mathrm{NS}$ \\
0:100 vs. mixes & --- & & 0.001 \\
100:0 vs. 0:100 & --- & & 0.001 \\
\hline L & &
\end{tabular}

${ }^{2} \mathrm{~L}=$ linear, $\mathrm{Q}=$ quadratic.

yTreatment comparisons made by single degree of freedom linear contrast tests. Mixes $=$ average of the 75:25, 50:50, and 25:75 $\mathrm{NH}_{4}{ }^{+}: \mathrm{NO}_{3}{ }^{-}$ratios.

${ }^{\text {Ns }}$ Nonsignificant at $P>0.05, P$ value stated otherwise. Sample date $\times \mathrm{NH}_{4}^{+}: \mathrm{NO}_{3}{ }^{-}$interaction was Ns. samples in a CHN elemental analyzer (Perkin Elmer 2400, Perkin Elmer). All tissue nutrient analyses were conducted at the Analytical Service Laboratory, Dept. of Soil Science. Leaf area of each species was determined at harvest with a leaf area meter (LI-3000; LICOR, Lincoln, Nebr.). Dry weight and leaf area data were used to calculate root : shoot ratio $[$ RSR $($ cotoneaster $)=$ root dry weight $\div$ shoot (leaf + stem) dry weight and RSR (rudbeckia $)=$ root dry weight $\div$ leaf dry weight $]$ and specific leaf dry weight (SLW = leaf dry weight $\div$ leaf area). Tissue nutrient content (mg) was based on percent concentration of the nutrient, multiplied by plant part (root or shoot) dry weight and divided by 100 , and was utilized to show absolute differences in nutrient accumulation regardless of plant size.

Histological procedures. After washing, two root subsamples $(1 \mathrm{~cm}$ long) from each species were collected from a primary root, 5 $\mathrm{cm}$ distally from the stem-root junction of the plant. Only roots of plants fertilized with 25:75 $\mathrm{NH}_{4}^{+}: \mathrm{NO}_{3}^{-}$and 0:100 $\mathrm{NH}_{4}^{+}: \mathrm{NO}_{3}^{-}$were sectioned (two plants per $\mathrm{NH}_{4}{ }^{+}: \mathrm{NO}_{3}{ }^{-}$treatment), based on conclusions drawn from root dry-weight analyses. Root tissue samples were fixed by vacuum infiltration with formalin acetic acid, dehydrated, infiltrated in a series of ethanol and tertiary butyl alcohol (Johansen, 1940), and embedded in TissuePrep (Fisher Scientific Co., Fairlawn, N.J.) using a Model 166 Histomatic Tissue Processor (Fisher Scientific Co.). Tissue samples were sectioned serially on a rotary microtome at 15 -mm thickness, affixed to slides with Haupt's adhesive (Jensen, 1962), and stained with safranin, methyl violet, and fast green (Johansen, 1940). Root diameter $(n=20)$, diameter of the stele ( $n$ $=20$ ), number of secondary tracheary elements $(n=10)$, size of secondary tracheary elements $(n=20)$, and number of cortical rows $(\mathrm{n}=10$, rudbeckia only) were determined by viewing cross sections of roots through a light microscope. Secondary tracheary elements were defined as secondary xylem $>10 \mathrm{~mm}$ in diameter.

Statistical analyses. All variables were tested for differences using analysis of variance and regression analyses (SAS Institute, 1985) and were considered significant at $P \leq$ 0.05 . Treatment comparisons were made by single degree of freedom linear contrast tests testing for differences between $\mathrm{NH}_{4}{ }^{+}$alone, $\mathrm{NO}_{3}{ }^{-}$alone, and the average response of $\mathrm{NH}_{4}{ }^{+}$ $: \mathrm{NO}_{3}{ }^{-}$mixtures. No statistical analyses were conducted on the anatomical data and these data are included for comparison purposes only.

\section{Results and Discussion}

Although $\mathrm{pH}$ of the nutrient solutions in stock tanks was maintained at 6.0 , substrate solution $\mathrm{pH}$ varied with sample date and $\mathrm{NH}_{4}{ }^{+}$ : $\mathrm{NO}_{3}{ }^{-}$ratio, while the interaction between sample date and $\mathrm{NH}_{4}{ }^{+}: \mathrm{NO}_{3}{ }^{-}$ratio was nonsignificant (Table 2). Substrate solution $\mathrm{pH}$ increased quadratically over the course of the experiment with the substrate solution $\mathrm{pH}$ starting at 6.34 on 25 Oct. and the highest $\mathrm{pH}$ measured on 12 Dec (6.92). There was also a quadratic response in substrate $\mathrm{pH}$ as effected by $\mathrm{NH}_{4}{ }^{+}: \mathrm{NO}_{3}{ }^{-}$ratio, with the highest $\mathrm{pH}$ measured in the substrate solution of plants fertilized with the 50:50 $\mathrm{NH}_{4}^{+}: \mathrm{NO}_{3}{ }^{-}$ratio.

Cotoneaster. Cotoneaster fertilized with $\mathrm{NO}_{3}{ }^{-}$alone had smaller leaf, stem, and root dry weights, less leaf area, and higher RSR than those fertilized with a combination of $\mathrm{NH}_{4}{ }^{+}$ and $\mathrm{NO}_{3}{ }^{-}$or with $\mathrm{NH}_{4}{ }^{+}$alone (Table 3). Similarly, dry weights of cranberry (Vaccinium macrocarpon Ait.) (Rosen et al., 1990), lodgepole pine, and Engelmann spruce (Bigg and Daniel, 1978) were higher with $\mathrm{NH}_{4}^{+}$and an equal mix of $\mathrm{NH}_{4}{ }^{+}$and $\mathrm{NO}_{3}{ }^{-}$(50:50) than with $\mathrm{NO}_{3}{ }^{-}$alone. In contrast, Gilliam et al. (198283) reported that $\mathrm{NO}_{3}{ }^{-}$increased shoot growth of cotoneaster 'Royal Beauty' compared to $\mathrm{NH}_{4}{ }^{+}$when applied weekly and grown in a substrate of 4 pine bark : 1 sand (by volume); however, $\mathrm{N}$ form did not impact root growth.

Nitrogen contents (mg) (Table 4) and concentrations (data not presented) in cotoneaster roots and shoots fertilized with $\mathrm{NO}_{3}{ }^{-}$were decreased an average of $54 \%$ and $26 \%$ for

Table 3. Effect of $\mathrm{N}$ form and ratio on cotoneaster leaf, stem, and root dry weights, root : shoot ratio (RSR), and leaf area.

\begin{tabular}{|c|c|c|c|c|c|}
\hline \multirow{2}{*}{$\begin{array}{l}\mathrm{NH}_{4}{ }^{+}: \mathrm{NO}_{3}{ }^{-} \\
\text {ratio }\end{array}$} & \multicolumn{4}{|c|}{ Dry wt $(\mathrm{g})$} & \multirow{2}{*}{$\begin{array}{c}\text { Leaf area } \\
\left(\mathrm{m}^{2}\right) \\
\end{array}$} \\
\hline & Leaf & Stem & Root & $\mathrm{RSR}^{\mathrm{z}}$ & \\
\hline $100: 0$ & 1.84 & 1.34 & 0.54 & 0.172 & 0.0372 \\
\hline $75: 25$ & 1.51 & 1.10 & 0.44 & 0.173 & 0.0296 \\
\hline $50: 50$ & 1.86 & 1.21 & 0.52 & 0.171 & 0.0338 \\
\hline $25: 75$ & 2.11 & 1.22 & 0.52 & 0.168 & 0.0315 \\
\hline $0: 100$ & 1.04 & 0.71 & 0.37 & 0.221 & 0.0207 \\
\hline \multicolumn{6}{|l|}{$\underline{\text { Regression }}^{y}$} \\
\hline $\mathrm{L}$ & NS & 0.02 & NS & 0.03 & 0.01 \\
\hline Q & NS & NS & NS & 0.03 & NS \\
\hline \multicolumn{6}{|l|}{ Contrasts $^{\mathrm{x}}$} \\
\hline 100:0 vs. mixes & NS & NS & NS & NS & NS \\
\hline 0:100 vs. mixes & 0.006 & 0.004 & 0.04 & 0.002 & 0.006 \\
\hline 100:0 vs. $0: 100$ & 0.02 & 0.002 & 0.02 & 0.002 & 0.001 \\
\hline
\end{tabular}

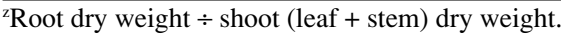

${ }^{{ } \mathrm{L}}=$ linear, $\mathrm{Q}=$ quadratic.

xTreatment comparisons made by single degree of freedom linear contrast tests. Mixes = average of the 75:25, 50:50, and 25:75 $\mathrm{NH}_{4}^{+}: \mathrm{NO}_{3}^{-}$ratios.

Nonsignificant at $P>0.05, P$ value stated otherwise. 
Table 4. Nitrogen form and ratio effects on cotoneaster root and shoot tissue nutrient contents.

\begin{tabular}{|c|c|c|c|c|c|c|c|c|c|c|}
\hline \multirow{2}{*}{$\begin{array}{l}\mathrm{NH}_{4}^{+}: \mathrm{NO}_{3}^{-} \\
\text {ratio }\end{array}$} & \multicolumn{5}{|c|}{ Root } & \multicolumn{5}{|c|}{ Shoot } \\
\hline & $\mathrm{N}$ & $\mathrm{P}$ & $\mathrm{K}$ & $\mathrm{Ca}$ & $\mathrm{Mg}$ & $\mathrm{N}$ & $\mathrm{P}$ & $\mathrm{K}$ & $\mathrm{Ca}$ & $\mathrm{Mg}$ \\
\hline 100:0 & 15.2 & 1.4 & 10.4 & 1.6 & 1.2 & 102.5 & 8.5 & 70.3 & 32.7 & 11.5 \\
\hline $75: 25$ & 12.0 & 1.3 & 9.4 & 1.5 & 1.1 & 83.2 & 7.0 & 57.8 & 29.2 & 9.8 \\
\hline $50: 50$ & 14.3 & 1.8 & 10.8 & 1.8 & 1.3 & 90.3 & 8.5 & 59.9 & 37.3 & 12.1 \\
\hline $25: 75$ & 12.2 & 1.9 & 11.6 & 2.3 & 1.6 & 96.9 & 9.4 & 63.7 & 44.0 & 13.3 \\
\hline $0: 100$ & 7.2 & 1.2 & 7.8 & 2.0 & 1.1 & 45.2 & 4.9 & 35.2 & 22.1 & 7.3 \\
\hline \multicolumn{11}{|l|}{$\underline{\text { Regression }}^{2}$} \\
\hline $\mathrm{L}$ & 0.007 & NS & NS & 0.004 & NS & 0.005 & NS & 0.002 & NS & NS \\
\hline Q & NS & 0.02 & NS & NS & NS & NS & NS & NS & 0.02 & 0.03 \\
\hline \multicolumn{11}{|l|}{ Contrasts $^{y}$} \\
\hline$\overline{100: 0}$ & & & & & & & & & & \\
\hline vs. mixes & 0.01 & 0.03 & NS & 0.03 & NS & 0.04 & NS & 0.004 & 0.02 & NS \\
\hline $0: 100$ & & & & & & & & & & \\
\hline vs. mixes & 0.001 & 0.001 & 0.006 & NS & 0.001 & 0.001 & 0.001 & 0.001 & 0.001 & 0.001 \\
\hline $100: 0$ & & & & & & & & & & \\
\hline vs. 0:100 & 0.001 & NS & 0.003 & 0.01 & NS & 0.001 & 0.001 & 0.001 & 0.003 & 0.001 \\
\hline
\end{tabular}

${ }^{2} \mathrm{~L}=$ linear, $\mathrm{Q}=$ quadratic.

yTreatment comparisons made by single degree of freedom linear contrast test. Mixes = average of the 75:25, 50:50, and 25:75 $\mathrm{NH}_{4}{ }^{+}: \mathrm{NO}_{3}{ }^{-}$ratios.

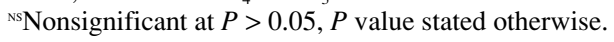

content and concentration, respectively, compared to $\mathrm{N}$ supplied as $\mathrm{NH}_{4}^{+}$alone, and $47 \%$ and $20 \%$ for content and concentration, respectively, compared to mixes of $\mathrm{NH}_{4}^{+}$and $\mathrm{NO}_{3}{ }^{-}$. In contrast, Gilliam et al. (1982-83) reported higher shoot $\mathrm{N}$ concentrations (percent dry weight) with weekly $\mathrm{NO}_{3}{ }^{-}$applica- tions to Cotoneaster dammeri 'Royal Beauty' grown in a substrate of 4 pine bark : 1 sand (by volume) than with weekly $\mathrm{NH}_{4}{ }^{+}$applications. Mixtures of $\mathrm{NH}_{4}^{+}$and $\mathrm{NO}_{3}^{-}$increased $\mathrm{P}, \mathrm{K}$, and $\mathrm{Mg}$ contents in cotoneaster roots and shoots compared to $\mathrm{NO}_{3}{ }^{-}$alone; whereas $\mathrm{NO}_{3}{ }^{-}$ lowered root $\mathrm{K}$ and $\mathrm{Ca}$ contents and shoot $\mathrm{P}$,
$\mathrm{K}, \mathrm{Ca}$, and $\mathrm{Mg}$ contents compared to $\mathrm{NH}_{4}^{+}$ alone (Table 4). Cotoneaster root and shoot $\mathrm{Fe}$ contents were not changed by $\mathrm{N}$ form, but mixtures of $\mathrm{NH}_{4}^{+}$and $\mathrm{NO}_{3}^{-}$, and $\mathrm{NH}_{4}^{+}$alone increased root and shoot $\mathrm{Mn}$ contents (data not presented).

Root diameter of cotoneaster was greater when fertilized with a mix of $\mathrm{NH}_{4}^{+}$and $\mathrm{NO}_{3}{ }^{-}$ compared to $\mathrm{NO}_{3}{ }^{-}$alone (Table 5). Diameter of the stele of cotoneaster roots was also larger with a mix of $\mathrm{NH}_{4}{ }^{+}$and $\mathrm{NO}_{3}{ }^{-}$than with $\mathrm{NO}_{3}{ }^{-}$ alone. Furthermore, roots fertilized with a mix of $\mathrm{NH}_{4}{ }^{+}$and $\mathrm{NO}_{3}^{-}$had a higher number of secondary tracheary elements that were slightly larger than with $\mathrm{NO}_{3}{ }^{-}$alone. Increased root dry weight when fertilized with mixtures of $\mathrm{NH}_{4}^{+}$ and $\mathrm{NO}_{3}^{-}$may have resulted from increased root diameter, since root length and area were unaffected by $\mathrm{N}$ form (Table 5). Root anatomy may be affected by the environment (Fahn, 1990), so the larger, more developed vascular system of cotoneaster roots fertilized with the mix of $\mathrm{NH}_{4}{ }^{+}$and $\mathrm{NO}_{3}{ }^{-}$may relate to the more favorable nutrient supply, resulting in a larger plant.

Rudbeckia. Similar to cotoneaster, $\mathrm{NO}_{3}{ }^{-}$as the sole N source produced lower leaf and root dry weights and smaller leaf area than rudbeckia fertilized with $\mathrm{NH}_{4}{ }^{+}$or with mixes of $\mathrm{NH}_{4}{ }^{+}$and $\mathrm{NO}_{3}{ }^{-}$(Table 6). Furthermore, plants in all treatments had equivalent specific leaf

Table 5. Total root area, total root length, and relative comparisons of the presence and diameter of root tissues and tissue systems (mean \pm standard error). Based on results of root dry weight analysis, only roots from $25: 75 \mathrm{NH}_{4}{ }^{+}: \mathrm{NO}_{3}{ }^{-}$and $0: 100 \mathrm{NH}_{4}{ }^{+}: \mathrm{NO}_{3}{ }^{-}$ratios were sectioned for root diameter, diameter of stele, number of secondary tracheary elements, and number of cortical rows determinations.

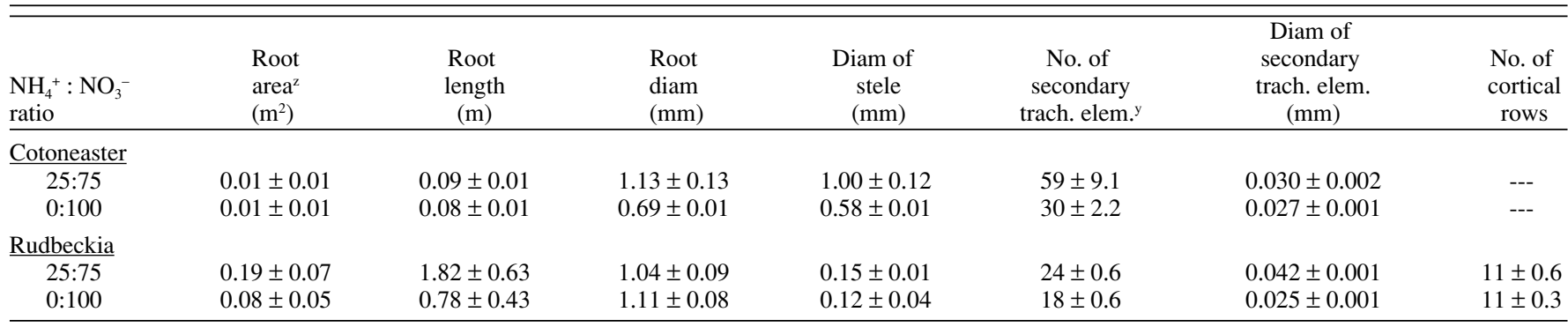

${ }^{2}$ Root area and root length were not affected by $\mathrm{NH}_{4}{ }^{+}: \mathrm{NO}_{3}{ }^{-}$ratio $(P>0.05)$. No statistical analyses were conducted on root diameter $(\mathrm{n}=20)$, diameter of the stele $(n=20)$, number of secondary tracheary elements $(n=10)$, size of secondary tracheary elements $(n=20)$, and number of cortical rows $(n=10$, rudbeckia only) data. These data are included for comparisons only.

${ }^{y}$ Secondary tracheary elements were defined as secondary xylem $\geq 10 \mathrm{~mm}$ in diameter.

Table 6. Effect of $\mathrm{N}$ form and ratio on rudbeckia leaf and root dry weights, root : shoot ratio (RSR), and leaf area.

\begin{tabular}{|c|c|c|c|c|}
\hline \multirow{2}{*}{$\begin{array}{l}\mathrm{NH}_{4}^{+}: \mathrm{NO}_{3}^{-} \\
\text {ratio }\end{array}$} & \multicolumn{3}{|c|}{ Dry weight $(\mathrm{g})$} & \multirow{2}{*}{$\begin{array}{c}\text { Leaf area } \\
\left(\mathrm{m}^{2}\right)\end{array}$} \\
\hline & Leaf & Root & $\mathrm{RSR}^{2}$ & \\
\hline 100:0 & 6.21 & 1.87 & 0.304 & 0.102 \\
\hline $75: 25$ & 6.66 & 2.15 & 0.341 & 0.114 \\
\hline $50: 50$ & 6.74 & 2.53 & 0.366 & 0.110 \\
\hline $25: 75$ & 6.19 & 2.38 & 0.417 & 0.105 \\
\hline $0: 100$ & 2.61 & 1.03 & 0.404 & 0.046 \\
\hline \multicolumn{5}{|l|}{ Regression $^{y}$} \\
\hline $\mathrm{L}$ & 0.04 & NS & 0.004 & 0.05 \\
\hline Q & 0.03 & 0.004 & NS & 0.03 \\
\hline \multicolumn{5}{|l|}{ Contrasts $^{\mathrm{x}}$} \\
\hline 100:0 vs. mixes & NS & NS & 0.05 & NS \\
\hline 0:100 vs. mixes & 0.001 & 0.002 & NS & 0.001 \\
\hline 100:0 vs. 0:100 & 0.009 & 0.03 & 0.03 & 0.02 \\
\hline
\end{tabular}

${ }^{2}$ Root dry weight $\div$ leaf dry weight.

${ }^{\mathrm{y}} \mathrm{L}=$ linear, $\mathrm{Q}=$ quadratic.

${ }^{x}$ Treatment comparisons made by single degree of freedom linear contrast tests. Mixes $=$ average of 75:25,

50:50, and 25:75 $\mathrm{NH}_{4}{ }^{+}: \mathrm{NO}_{3}{ }^{-}$ratios.

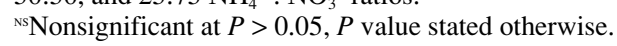


Table 7. Nitrogen form and ratio effects on rudbeckia root and shoot tissue nutrient contents.

\begin{tabular}{|c|c|c|c|c|c|c|c|c|c|c|}
\hline \multirow{2}{*}{$\begin{array}{l}\mathrm{NH}_{4}^{+}: \mathrm{NO}_{3}^{-} \\
\text {ratio }\end{array}$} & \multicolumn{5}{|c|}{ Root } & \multicolumn{5}{|c|}{ Shoot } \\
\hline & $\mathrm{N}$ & $\mathrm{P}$ & $\mathrm{K}$ & $\mathrm{Ca}$ & $\mathrm{Mg}$ & $\mathrm{N}$ & $\mathrm{P}$ & $\mathrm{K}$ & $\mathrm{Ca}$ & $\mathrm{Mg}$ \\
\hline 100:0 & 101.2 & 19.6 & 114.9 & 6.1 & 9.1 & 220.3 & 27.1 & 239.7 & 190.3 & 84.9 \\
\hline $75: 25$ & 101.7 & 24.4 & 135.2 & 6.5 & 10.3 & 254.0 & 39.5 & 317.5 & 190.7 & 72.2 \\
\hline $50: 50$ & 106.6 & 29.8 & 156.4 & 8.8 & 12.2 & 255.7 & 35.3 & 332.5 & 184.5 & 72.1 \\
\hline $25: 75$ & 95.4 & 26.2 & 153.6 & 7.5 & 13.2 & 254.4 & 47.0 & 273.4 & 177.7 & 65.8 \\
\hline $0: 100$ & 43.7 & 10.1 & 70.6 & 3.6 & 5.7 & 104.0 & 28.0 & 99.6 & 81.5 & 28.4 \\
\hline \multicolumn{11}{|l|}{ Regression $^{2}$} \\
\hline $\mathrm{L}$ & 0.003 & NS & NS & NS & NS & 0.03 & NS & 0.04 & 0.001 & 0.001 \\
\hline Q & 0.001 & 0.001 & 0.001 & 0.001 & 0.002 & 0.001 & 0.03 & 0.001 & 0.003 & 0.02 \\
\hline \multicolumn{11}{|l|}{ Contrasts $^{\mathrm{y}}$} \\
\hline$\overline{100: 0}$ vs. mixes & NS & 0.004 & 0.001 & 0.007 & 0.001 & 0.007 & 0.03 & 0.002 & NS & 0.01 \\
\hline 0:100 vs. mixes & 0.001 & 0.001 & 0.001 & 0.001 & 0.001 & 0.001 & 0.04 & 0.001 & 0.001 & 0.001 \\
\hline $100: 0$ vs. $0: 100$ & 0.001 & 0.002 & 0.001 & 0.005 & 0.001 & 0.001 & NS & 0.001 & 0.001 & 0.001 \\
\hline
\end{tabular}

${ }^{\mathrm{z}} \mathrm{L}=$ linear, $\mathrm{Q}=$ quadratic.

y Treatment comparisons made by single degree of freedom linear contrast tests. Mixes $=$ average of the 75:25, 50:50, and 25:75 $\mathrm{NH}_{4}^{+}: \mathrm{NO}_{3}{ }^{-}$ratios.

Nonsignificant $P>0.05, P$ value stated otherwise.

dry weights $\left(60 \mathrm{~g} \cdot \mathrm{m}^{-2}\right)$, indicating that differences in leaf area were due to changes in leaf expansion or number, not leaf thickness. There were no differences in leaf and root dry weights of plants fertilized with $\mathrm{NH}_{4}^{+}$and plants fertilized with mixes of $\mathrm{NH}_{4}{ }^{+}$and $\mathrm{NO}_{3}{ }^{-}$, suggesting that any addition of $\mathrm{NH}_{4}{ }^{+}$to fertilizer solutions improved growth. The RSR was lower with $\mathrm{NH}_{4}{ }^{+}$than if $\mathrm{N}$ was supplied as mixes of $\mathrm{NH}_{4}^{+}$ and $\mathrm{NO}_{3}^{-}$, or as $\mathrm{NO}_{3}^{-}$alone, indicating that energy was allocated to shoot growth at the expense of root growth. Similarly, Klett and Gartner (1975) reported that growth of Chrysanthemum morifolium Ramat. 'Bright Golden Anne' in hardwood bark was higher with an equal mix of $\mathrm{NH}_{4}^{+}$and $\mathrm{NO}_{3}^{-}$than with $\mathrm{N}$ supplied as $\mathrm{NH}_{4}^{+}$or $\mathrm{NO}_{3}^{-}$alone.

Roots and shoots of rudbeckia fertilized with $100 \% \mathrm{NO}_{3}^{-}$had lower contents of $\mathrm{N}, \mathrm{K}$, $\mathrm{Ca}$, and $\mathrm{Mg}$ than plants fertilized with $\mathrm{NH}_{4}{ }^{+}$ alone and mixes of $\mathrm{NH}_{4}{ }^{+}$and $\mathrm{NO}_{3}{ }^{-}$(Table 7). Similarly, $\mathrm{NH}_{4}{ }^{+}$resulted in higher $\mathrm{N}$ contents in shoots of Chrysanthemum morifolium 'Bright Golden Anne' than $\mathrm{NO}_{3}{ }^{-}$(Klett and Gartner, 1975). Phosphorus contents in roots and shoots fertilized with mixes of $\mathrm{NH}_{4}^{+}$and $\mathrm{NO}_{3}^{-}$were $20 \%$ to $75 \%$ higher than those fertilized with $\mathrm{NH}_{4}^{+}$or $\mathrm{NO}_{3}^{-}$alone (Table 7). Such dramatic reductions in tissue nutrient content and growth reiterate the need for proper $\mathrm{N}$ form selection. Maximum nutrient content was generally found with the 50:50 $\mathrm{NH}_{4}^{+}$: $\mathrm{NO}_{3}^{-}$ratio, which also corresponds to maximum leaf and root dry weights (Table 6). Shoot Fe contents were higher in plants fertilized with mixtures of $\mathrm{NH}_{4}^{+}$and $\mathrm{NO}_{3}^{-}$than in those fertilized with $\mathrm{NH}_{4}{ }^{+}$or $\mathrm{NO}_{3}{ }^{-}$alone, but $\mathrm{NH}_{4}{ }^{+}$resulted in the greatest $\mathrm{Mn}$ contents in shoots and roots (data not presented).

Root diameter of rudbeckia fertilized with a mix of $\mathrm{NH}_{4}{ }^{+}$and $\mathrm{NO}_{3}{ }^{-}$was similar to those grown with $\mathrm{NO}_{3}{ }^{-}$alone (Table 5) even though root dry weight was higher with the mixes of $\mathrm{NH}_{4}{ }^{+}$and $\mathrm{NO}_{3}{ }^{-}$than with $\mathrm{NO}_{3}{ }^{-}$alone (Table 6). This result suggests that increased root dry weight with a mix of $\mathrm{NH}_{4}{ }^{+}$and $\mathrm{NO}_{3}{ }^{-}$might be due to increased root length and/or root number instead of increased diameter. Root length was not changed by $\mathrm{N}$ form (Table 5), so a greater number of roots with a mix of $\mathrm{NH}_{4}^{+}$and
$\mathrm{NO}_{3}{ }^{-}$may have resulted in increased dry weight. Diameter of the stele of rudbeckia roots and number of rows of cortical layers did not differ with $\mathrm{N}$ form (Table 5). However, stele of roots exposed to a mix of $\mathrm{NH}_{4}{ }^{+}$and $\mathrm{NO}_{3}{ }^{-}$had more secondary xylem with larger tracheary elements than stele of roots exposed to $\mathrm{NO}_{3}{ }^{-}$ alone. A mixture of $\mathrm{NH}_{4}{ }^{+}$and $\mathrm{NO}_{3}{ }^{-}$resulted in a larger rudbeckia plant and a larger, more developed vascular system in rudbeckia roots.

In summary, growth and mineral nutrient accumulation of cotoneaster, a woody plant, and rudbeckia, an herbaceous plant, were generally higher with $\mathrm{NH}_{4}^{+}$, or if $\mathrm{NH}_{4}^{+}$was mixed with $\mathrm{NO}_{3}^{-}$, than with $\mathrm{NO}_{3}^{-}$alone. Nutrient solutions containing $\mathrm{NH}_{4}{ }^{+}$resulted in a marked increase in shoot and root growth of both species. A similar response was found if $\mathrm{NH}_{4}^{+}$ was applied to a broad range of plants already being grown with $\mathrm{NO}_{3}^{-}$(Kirkby, 1981; Mengel and Kirkby, 1982). Root diameter of the woody roots of cotoneaster was higher with a mix of $\mathrm{NH}_{4}{ }^{+}$and $\mathrm{NO}_{3}{ }^{-}$than with $\mathrm{NO}_{3}{ }^{-}$alone, whereas diameter of the herbaceous roots of rudbeckia was not impacted by $\mathrm{N}$ form. Nutrient solutions with a mixture of $\mathrm{NH}_{4}^{+}$and $\mathrm{NO}_{3}^{-}$appeared to increase root diameter of the woody roots of cotoneaster and to result in a greater number of roots with the herbaceous rudbeckia. Steles of both plants contained more secondary xylem with larger tracheary elements with a mix of $\mathrm{NH}_{4}{ }^{+}$and $\mathrm{NO}_{3}{ }^{-}$than with nutrient solutions containing $\mathrm{NO}_{3}^{-}$alone. Increased number and size of secondary tracheary elements may relate to increased dry weight and leaf area of both cotoneaster and rudbeckia fertilized with mixes of $\mathrm{NH}_{4}{ }^{+}$and $\mathrm{NO}_{3}{ }^{-}$ rather than with $\mathrm{NO}_{3}{ }^{-}$alone. The surface area of the root system correlates to leaf surface area, so there may also be some correlation between size of the water-conducting system and the leaf area supplied by it (Kramer, 1983). Adaptations in the anatomical features of xylem are related to moisture availability, transpiration, and requirements for mechanical strength (Fahn, 1990). As utilization of $\mathrm{N}$ compounds is regulated by hormonal activity (Kirkby, 1981), higher transpirational demand may induce a hormonal signal for increased secondary tracheary differentiation.

\section{Literature Cited}

Bigg, W.L. and T.W. Daniel. 1978. Effects of nitrate, ammonium, and $\mathrm{pH}$ on the growth of conifer seedlings and their production of nitrate reductase. Plant Soil 50:371-385.

Edwards, J.H. and B.D. Horton. 1982. Interaction of peach seedlings to $\mathrm{NO}_{3}{ }^{-}: \mathrm{NH}_{4}{ }^{+}$ratios in nutrient solutions. J. Amer. Soc. Hort. Sci. 107:142-147.

Fahn, A. 1990. Plant anatomy. Pergamon Press, Elmsford, N.Y.

Finn, C.E., C.J. Rosen, and J.J. Luby. 1990. Nitrogen and solution $\mathrm{pH}$ effects on root anatomy of cranberry. HortScience 25:1419-1421.

Gilliam, C.H., T.A. Fretz, and W.J. Sheppard. 1980. Effect of nitrogen form and rate on elemental content and growth of pyracantha, cotoneaster, and weigela. Scientia Hort. 13:173-179.

Gilliam, C.H., M.E. Watson, and W.J. Sheppard. 1982/83. Fertilization of cotoneaster in a pine bark medium. Scientia Hort. 18:185-190.

Hiller, L.K. and D.C. Koller. 1979. Potato growth responses in arcillite and sand. HortScience 14:534-536.

Jensen, W.A. 1962. Botanical histochemistry. W.H. Freeman, San Francisco.

Johansen, D.A. 1940. Plant microtechnique. McGraw-Hill, New York.

Kirkby, E.A. 1981. Plant growth in relation to nitrogen supply, p. 249-267. In: F.E. Clark and T. Rosswall (eds.). Terrestrial nitrogen cycles, processes, ecosystem strategies and management impacts. Ecol. Bul. 33:249-267.

Klett, J.E. and J.B. Gartner. 1975. Growth of chrysanthemums in hardwood bark as affected by nitrogen source. J. Amer. Soc. Hort. Sci. 100:440-442.

Kramer, P.J. 1983. Water relations of plants. Academic, San Diego.

Marschner, H. 1986. Mineral nutrition of higher plants. Academic, London.

Mengel, K. and E.A. Kirkby. 1982. Principles of plant nutrition. Intl. Potash Inst., WorblaufenBern, Switzerland.

Rosen, C.J., D.L. Allen, and J.J. Luby. 1990. Nitrogen form and solution $\mathrm{pH}$ influence growth and nutrition of two Vaccinium clones. J. Amer. Soc. Hort. Sci. 115:83-89.

SAS Institute. 1985. SAS user's guide: Statistics. Version 5 ed. SAS Inst., Cary, N.C.

Thetford, M., S.L. Warren, and F.B. Blazich. 1995. Response of Forsythia ×intermedia 'Spectabilis' to uniconazole. I. Growth; dry-matter distribution; and mineral nutrient content, concentration, and partitioning. J. Amer. Soc. Hort. Sci. 120:977-982. 